\title{
Correction to: Effect of size and shape of specimens on the mass loss caused by Coniophora puteana in wood durability tests
}

\author{
Christian Brischke $^{1}$ (D) . Leopold K. Grünwald ${ }^{1}$. Susanne Bollmus ${ }^{1}$
}

Published online: 29 June 2021

○) Springer-Verlag GmbH Germany, part of Springer Nature 2021

\section{Correction to: \\ European Journal of Wood and Wood Products (2020) 78:811-819 \\ https://doi.org/10.1007/s00107-020-01559-0}

The article: Effect of size and shape of specimens on the mass loss caused by Coniophora puteana in wood durability tests, written by Christian Brischke · Leopold K. Grünwald - Susanne Bollmus was originally published electronically on the publisher's internet portal (currently SpringerLink) on 30 June 2020 without open access.

With the author(s)' decision to opt for Open Choice the copyright of the article changed on 25 June Christian Brischke ${ }^{1} \cdot$ Leopold K. Grünwald ${ }^{1} \cdot$ Susanne Bollmus ${ }^{1}$

2021 (c) The Author(s) 2021 and the article is forthwith distributed under the terms of the Creative Commons Attribution 4.0 International License (http://creativecommons. org/licenses/by/4.0/), which permits use, duplication, adaptation, distribution and reproduction in any medium or format, as long as you give appropriate credit to the original author(s) and the source, provide a link to the Creative Commons license and indicate if changes were made.

The original article can be found online at https://doi.org/10.1007/ s00107-020-01559-0.

Christian Brischke

christian.brischke@uni-goettingen.de

http://www.uni-goettingen.de/en/67096.html

1 Wood Biology and Wood Products, University

of Goettingen, Buesgenweg 4, 37077 Göttingen, Germany
Open Access This article is distributed under the terms of the Creative Commons Attribution 4.0 International License (http://creativecommons.org/licenses/by/4.0/), which permits unrestricted use, distribution, and reproduction in any medium, provided you give appropriate credit to the original author(s) and the source, provide a link to the Creative Commons license, and indicate if changes were made.

The original article was corrected. 